
their education. Journal of Education, Health and Sport. 2020;10(2):148-152. eISSN 2391-8306. DOI http://dx.doi.org/10.12775/JEHS.2020.10.02.020

https://apcz.umk.pl/czasopisma/index.php/JEHS/article/view/JEHS.2020.10.02.020

https://zenodo.org/record/3688755

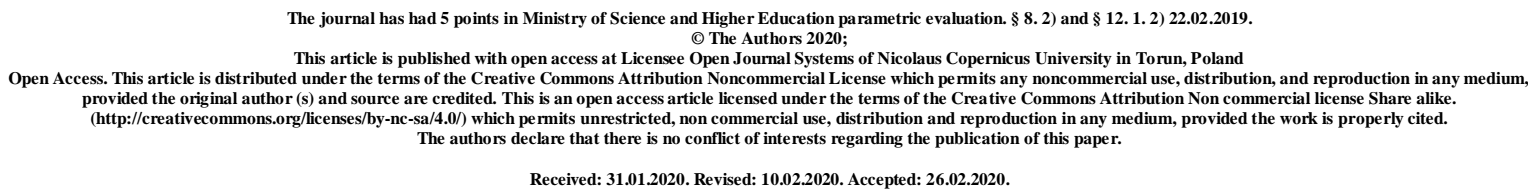

UDK 159.91:614-053.2

\title{
RELATIONSHIP OF THE PSYCHOSOMATIC STATUS OF PEDIATRIC INTERNS AND THE EFFICIENCY OF THEIR EDUCATION
}

\author{
O. K. Koloskova \\ Professor, Head of Department of Pediatrics and Children Infectious Diseases \\ HSEE of Ukraine «Bukovinian State Medical University»
}

V.S. Khilchevska

$\mathrm{PhD}$, Associate Professor, Department of Pediatrics and Children Infectious Diseases HSEE of Ukraine «Bukovinian State Medical University»

\author{
G. A. Bilyk \\ $\mathrm{PhD}$, Associate Professor, Department of Pediatrics and Children Infectious Diseases \\ HSEE of Ukraine «Bukovinian State Medical University»
}

\begin{abstract}
The results of a study of psychoemotional and psychosomatic status in a group of interns who are trained in an internship in the specialty "Pediatrics" are presented. It is established that changes in the psychosomatic status and personal characteristics of interns have a significant negative impact on the results of their training.

In conducting the survey of interns-pediatricians found average levels of personal anxiety, extraversion and neuroticism. It should also be emphasized that signs of autonomic dysfunction were diagnosed in $65.0 \%$ of interns. The results of the final certification of interns were positively associated with their level of motivation $(r=0.40, p<0.05)$ and the severity of autonomic dysfunction $(\mathrm{r}=0.58, \mathrm{p}<0.05)$. It was established a feedback between the results of certification with complaints of pain syndrome of various localization $(r=-0.37$,
\end{abstract}


$\mathrm{p}<0.05)$, complaints from the cardiovascular system $(\mathrm{r}=-0.42, \mathrm{p}<0.05)$ and the level of personal anxiety $(\mathrm{r}=-0.36, \mathrm{p}<0.05)$.

\section{Keywords: postgraduate education; internship; pediatrics; psychoemotional} state.

Introduction. The internship is the most important and unique stage in training of the future doctor. Most of the knowledge and practical skills in the profession are mastered precisely at this stage of postgraduate training $[2,7]$. Internship training and working in a medical institutions need from intern except good physical fitness also sufficient personal endurance. It is known that quality of the learning process and its results depend on the functional state of the learning subject. The most significant factors which affect the functional status of the future doctor are biological (age, gender, occupational hazards), psychoemotional and intellectual loads $[1,6]$.

A prolonged state of mental and emotional stress before the responsible exam which summarizes the activities of interns over two years of internship can exacerbate such negative personality traits as personal anxiety, neuroticism, impaired communication skills and, as a result, impairment of the acquired knowledge and skills, occurrence of psychosomatic pathology and, in general, decrease motivation to improve professional qualities and knowledge [1].

Goal of the research. Overall goal of research is a study the psychoemotional state of interns in the specialty "Pediatrics" in the pre-certification period at the end of a two-year internship.

Material and methods. Thirty-four interns who graduate from a two-year internship at the Department of Pediatrics and Children's Infectious Diseases of Higher State Educational Establishment of Ukraine «Bukovinian State Medical University» in 2016-2018 were observed during the research. The analyzed results of the final state appraisal in relation with a current success indicators and a features of psychosomatic and emotional state interns which were evaluated using the stress tolerance scale, Eysenck test, Spielberger personal anxiety test [5], and Zung Self-Rating Depression Scale [4]. The association of the results of the final exam with the psychosomatic status of the interns was determined by self-assessment of well-being using the Giessen test (a technique for detecting the intensity of psychosomatic complaints) [5]. Assessment of the state of the autonomic nervous system was carried out using a questionnaire to identify signs of autonomic dysfunction syndrome according to A. M. Wayne [3]. 
The results were analyzed using the statistical program Statistica for Windows v.8.0 (Statsoft, USA) using the methods of variation statistics and correlation analysis.

Results and discussion. A comparative analysis of the results of training interns for final certification in the period 2016-2018. showed stable dynamics of the average score (4.04.18) and a fairly high indicator of quality performance (75.0-81.8\%). It is can be explain by the high requirements for full-time study at the internship, the emphasis on the resulting assessment at the level of practical skills and the quality of competency-based training of interns during the academic year at distance learning bases.

According to the correlation analysis, the results of state certification were closely related to baseline knowledge $(r=0,44, p<0,05)$, the results of the multidisciplinary module "Emergency conditions" ( $\mathrm{r}=0.83, \mathrm{p}<0.05)$, the licensed test exam «KROK-3. General medical training» $(\mathrm{r}=0.83, \mathrm{p}<0.05)$, semi-annual and annual certifications $(\mathrm{r}=0.83$ and $\mathrm{r}=0.85$, respectively, $\mathrm{p}<0.05)$.

During the analysis of the survey data was found that certain psychoemotional and psychosomatic characteristics of interns inevitably worsened the performance of the final certification. In conducting the survey of interns-pediatricians found average levels of personal anxiety, extraversion and neuroticism. At the same time, the level of extraversion was higher, and the level of anxiety and neuroticism was slightly lower in women than in men. It should also be emphasized that signs of autonomic dysfunction were diagnosed in $65.0 \%$ of interns. In determining resistance to stressful situations, interns generally showed a fairly high level. The results of the final certification of interns were positively associated with their level of motivation $(r=0.40, p<0.05)$ and the severity of autonomic dysfunction $(\mathrm{r}=0.58, \mathrm{p}<0.05)$.

The last correlation can probably be represented as the result of long hard work in preparing a large number of questions on pediatric sand constant readiness for several stages of final control. Also it was established a feedback between the results of certification with complaints of pain syndrome of various localization (more often with headache) $(r=-0.37$, $\mathrm{p}<0.05)$, complaints from the cardiovascular system $(\mathrm{r}=-0.42, \mathrm{p}<0.05)$ and the level of personal anxiety $(r=-0.36, p<0.05)$. Apparently, the worse prepared students were most anxious or it adversely affected the results of the final exam.

It should be noted that with the indicators of stress instability, a tendency to depressive state, extraversion and neuroticism, the results of the final certification were not reliably associated, that indicating readiness and sufficient adaption of future pediatricians to stressful situations associated with multicomponent (test exam, practical skills, theoretical survey) 
assessment of their professional level regardless of the characteristics of their personality traits.

Conclusions. Thus, the psychosomatic features of the state of interns definitely worsen the results of their final certification, and overstrain in the pre-certification period is manifested by the psychosomatic variant of maladaptation to environmental influences. In order to improve and maintain the health of future doctors, increase their adaptive properties and resistance to stress and optimize the educational process and train full-fledged specialists throughout the training, it is advisable to regularly conduct a psychophysiological diagnosis of their functional state and timely correction of revealed violations.

In perspective, the results of such studies should be used to identify signs of a decrease in professional motivation and adaptation, symptoms of emotional burnout for interns and also to justify the conduct of trainings on the valeological aspects of maintaining health, technologies for conflict free communication, stress management and developing psychological defense skills.

\section{References}

1. Ananich Yu.G., Zhizhin K.S., Kvasov A.R. Valeologicheskoe soderzhanie socialno-gigienicheskogo monitoringa zdorovya internov [Valeological content of social and hygienic monitoring of the health of interns]. Valeologiya, 2008;3:25-30. (in Russian)

2. Bezrukov L.A., Koloskova E.K., Khilchevskaya V.S. Obuchenie internovpediatrov kak upravlyaemyj process [Training of interns-pediatricians as a controlled process]. Probl. pit. pediatriyi ta vishoyi med. osviti: zb. nauk. prac, prisvyachenih pam'yati profesora Yu.M.Vitebskogo [Issues of Pediatrics and Higher Medical Education: Collection of scientific works, in honor of the memory of Professor Yu.M. Vitebsky]. Donetck.2008;232-235. (in Russian)

3. Vejn A.M. Nevrologiya nespecificheskih sistem mozga. [Neurology of nonspecific brain systems]. $\mathrm{V}$ sb.: Nevrologiya nespecificheskih sistem mozga. [In: Neurology of nonspecific brain systems].- M.:MMI named after I.M.Sechenova,1988 .- 120 p. (in Russian)

4. Burlachuk L.F., Morozov S.M. Slovar-spravochnik po psihologicheskoj diagnostike [Dictionary-guide for psychological diagnostic] editor in chief Krymsky S.B. K :Naukova Dumka,1989.- 200 p. (in Russian)

5. Spilberger Ch.D. Konceptualnye i metodologicheskie problemy issledovaniya trevogi. [Conceptual and methodological problems of anxiety research] // Stress i trevoga v sporte, M.: Sport, 1983:55-70. (in Russian) 
6. Tkacheva M.Yu., Stadnik A.D., Chudnovskij A.A. Vliyanie psihoemocionalnyh osobennostej lichnosti na kachestvo zhizni vrachej anesteziologov v period poslediplomnogo obrazovaniya [Influence of psych-emotional personality traits on the quality of life of anesthetists during postgraduate education]. Ukrayinskij medichnij almanah, 2014.17(4): 97-101. (in Russian)

7. Khilchevskaya V.S., Bilous T.M. Analiz effektivnosti podgotovki k ekzamenu «KROK-3. Obshaya vrachebnaya podgotovka vrachej-internov specialnosti «pediatriya» [Analysis of the effectiveness of preparation for the exam "KROK3. General medical preparation interns of the specialty "Pediatrics"]. Materialy X mezinarodnivedecko prakticka konference "Effektivni nastroje modernichved - 2014, Praha. 2014; 23-26 (in Russian) 